\title{
PROVISION OF SUPPLEMENTARY FOOD FOR SASIGO AND BISCUIT IN INCREASING THE WEIGHT OF CHILDREN : A COMPARATIVE STUDY IN NAMBO PRIMARY HEALTH CARE IN KENDARI CITY
}

\author{
Mariyatni Rasyid ${ }^{1}$, Timbul Supodo ${ }^{2}$, La Banudi $^{3}$ \\ ${ }^{1,2,3}$ Magister of Public Health Study Program, Universitas Mandala Waluya \\ In Kendari, Southeast Sulawesi Province, Indonesia
}

Corresponding Author : Mariyatni Rasyid

Email : -

\begin{abstract}
Background:The prevalence of community nutritional status in the Kendari City area in 2016 was $0.23 \%$. In 2017 , the prevalence of nutritional status decreased in $0.13 \%$ and then increased in 2018 by $4.67 \%$. in 2019 , the prevalence of nutritional status decreased by $2.25 \%$. Thus, children under five have nutritional status did not reached the target This study aimed to understand the effect of giving the sasigo and biscuit on increase the children's weight in Nambo Primary Health Care in Kendari City.

Methods:The type of research in this research is pre-experimental research with a Pre Test Post Test design. This research was conducted in the working area of Nambo Primary Health Care, Kendari City. Population were 227 and a sample was 67 malnourished toddlers in 2019. Result:Based on the independent sample test output in the Equal Variances Assumed section on Local supplementaty food (BageaSasigo), it is known that the sig (2-tailed) value is 0.001 $<0.05$, so $\mathrm{Ha}$ is accepted so that there is a significant difference between the provision of local supplementary food (BageaSasigo). Whereas in the Government PMT (biscuits) it is known that the sig (2-tailed) value is $0.000<0.05$, so $\mathrm{Ha}$ is accepted so that there is a significant difference between the provision of government PMT (biscuits) to toddlers in the Work Area of the Nambo Primary Health Care, Kendari City.

Conclusion:Provision of Local supplementary food (Bagea Sasigo) and Government SP (Biscuits) for toddlers. Before giving the intervention it was not effective while after giving the intervention it was effective and significant.
\end{abstract}

Key words: Food, Biscuits, Nutrition, Toddlers

Indonesian Journal Of Health Sciences Research and Development 


\section{INTRODUCTION}

World Health Organization (WHO) explained that nutritional problems can be indicated by the large incidence of malnutrition in that country. In Indonesia in 2015, monitoring of nutritional status showed that $79.9 \%$ of good nutrition, $14.9 \%$ of malnutrition, $3.8 \%$ of malnutrition and $1.5 \%$ of overnutrition. In the nutritional status of toddlers according to the height index according to age, the results were $71 \%$ normal, $29.9 \%$ short and very short. Meanwhile, for the nutritional status of children under five according to the weight index according to height, the results were $82.7 \%$ normal, $8.2 \%$ thin, $5.3 \%$ fat and $3.7 \%$ very thin(1).

The prevalence of community nutritional status in the Kendari City area in 2016 was $0.23 \%$, decreased in 2017 by $0.13 \%$, increased in 2018 by $4.67 \%$ and decreased by $2.25 \%$ in 2019 Although the prevalence rate of nutrition tends to decrease, although not significantly, the problem is nutritional statusthere are still many in the Kendari City Area. Thus Kendari City shows that children under five have not reached the target of nutritional status, where the current nutritional status of children under five is $0.21 \%$ while the Minimum Service Standard is $8.1 \%(2)$.

Based on the initial survey and observations carried out, in the working area of the Nambo Puskesmas, which is the Puskesmas with malnourished children under five, the highest is 227 under 15 health centers in Kendari City. From the results of observations, the cause of high malnutrition is due to the behavior of mothers, especially in the provision of food intake to children under five and eating care in providing food, they are more interested in fast food but contain preservatives and lack of nutrients, especially protein, vitamins and minerals so that many toddlers prefer to eat fast food. fast food and the level of activities of mothers helping their husbands to earn a living so that they do not bring their toddlers to the posyandu so that they cannot monitor growth and development which causes malnutrition in children under five.

Cassava is used as a material for making bagea because cassava is one of the secondary crops which is the third food ingredient after rice and corn. Cassava as one of the most important commodities in Indonesia should be encouraged and developed for its products in the context of agricultural diversification and food diversification, which are currently being implemented(3).

Bagea cake is a typical snack in the Kendari mainland. This cake has a dry texture a bit hard and tastes sweet and savory. Judging from the basic ingredients of the bagea cake made from sago, this bagea cake has a characteristic because besides it tastes good, this bagea cake is also unique because it is almost similar to biscuits(4).

This study provides a form of PMT in the form of snacks (Bagea) made from local sago with added gonads. This Bagea is a modification of the traditional Tolaki ethnic food with the regional name Bagea Cake. Bagea is made from a mixture of sago, sugar, chicken eggs and added with sea urchins, which is almost the same shape as sago biscuits. Based on (5), the development of supplementary feeding with complementary breastmilk in addition to paying attention to biological values must also pay attention to prices so that they are affordable and processed by taking into account the eating habits of local communities.

The added PMT biscuits in this study were to see the differences in body weight of toddlers who consumed Sasigo bagea and PMT biscuits(6). The use of PMT from the government is usually given to children aged 6-59 months who experience nutritional problems. the content of PMT biscuits is a nutritional supplement in the form of additional food in the form of crackers with special formulations and fortified with vitamins and minerals and enriched with vitamins B1, B2, B3, B5, B6 and B12, folic acid and seven (7) kinds of minerals (Iron, Calcium, Sodium, Zinc, Iodine, Phosphorus 
and Selenium) are given to children to meet their nutritional needs (7).

Indicators of improvement in nutritional status were measured using anthropometry. Anthropometric indicators consist of weight and height. Weight is the most important and most frequently used anthropometric measure. Body weight describes the amount of protein, fat, water and minerals in the bones. A person's weight is influenced by several factors, including age, gender, physical activity and heredity (8). For indicators, height is an important parameter for past nutritional conditions and current conditions if age is not known accurately(9).

\section{METHOD}

The type of research that will be used in this research is pre-experimental research with a Pre Test - Post Test design which is used to see the differences before and after treatment $(10)$. This research was conducted in the work area of PuskesmasNambo, Kendari City for one (1) month, starting from September to October 2020. The population in this study were children under five with malnutrition in the work area of PuskesmasNambo as many as 227 children with a sample of 67 nutritional infants. less in 2019.Sampling in this study using the Probability Sampling Technique, namely cluster sampling and simple random sampling(11).

\section{RESULT}

Table 1.It shows that of the 67 respondents who consumed local PMT (BageaSasigo), the highest frequency was in the 8-20 month age category, namely 29 respondents $(43.3 \%)$ and the lowest frequency was in the $>40$ months age category, namely 6 respondents $(9.0 \%)$.

Table 2.It shows that out of 67 respondents who consume Government PMT (Biscuits), the highest frequency is in the 3140 months and $>40$ months age category, respectively 18 respondents $(26.9 \%)$ and the lowest frequency is in the 8-20 months age category. 15 respondents $(22.4 \%)$.

Table 3.It is known that before the treatment was given, namely Local PMT (BageaSasigo) and Government PMT (Biscuits), which was 0, while after treatment with the provision of Local PMT (BageaSasigo) and Government PMT (Biscuits), namely 67 respondents (50\%) respectively. with the research procedure, namely for 4 weeks of treatment.

Table 4.It is known that before being given treatment (Pre Test), namely Local PMT (BageaSasigo) for body weight amounted to 67 respondents $(100 \%)$ while after treatment (Post Test) by giving Local PMT (BageaSasigo) for body weight category fixed (negative) totaled 42 respondents $(62.7 \%)$. Whereas for the positive category (increasing) after getting treatment, namely the provision of Local PMT (BageaSasigo) amounted to 25 respondents $(23.7 \%)$.

Table 5.It is known that before being given treatment (Pre Test), namely Government PMT (Biscuits) for body weight amounted to 67 respondents $(100 \%)$ while after treatment (Post Test) by giving Government PMT (Biscuits) for body weight category fixed (negative) amounted to 22 respondents $(32.8 \%)$. Meanwhile, for the positive category (increased) after receiving treatment, namely the provision of Government PMT (Biscuits) amounted to 45 respondents $(67.2 \%)$.

Table 6 is known that of the 67 respondents who were given Local PMT (BageaSasigo) treatment before being given treatment (Pre Test) which is 9.4 times then after treatment (Post Test) by giving Local PMT (BageaSasigo) to 9.5 times. The difference between the average BageaSasigo Pre-Test and Post-Test is 0.1 times.

Table 7 is known that of the 67 respondents who were given the Government PMT (Biscuits) treatment before being given the treatment (Pre Test) which was 10.5 times then after the treatment (Post Test) was given the Government PMT (Biscuits) to 11 
Rasyid, M., T. Supodo, \& L. Banudi. DOI: 10.36566/ijhsrd/Vol3.Iss1/53 https://ijhsrd.com/index.php/ijhsrd

e- ISSN: $\mathbf{2 7 1 5 - 4 7 1 8}$

times. The difference between the average BageaSasigo Pre-Test and Post-Test is 0.5 times.

Table 8 is known that from 67 respondents, the value of sig. Levene's Test for Equality of Variances on bageasasigo is
$0.129>0.05$, it means that the variance of the Case group data is Homogeneous or the same (V. WiratnaSujarweni, 2014). While for the Biscuits the amount of 0.052>0.05, it means that the data variance of the Control group is Homogeneous or the same.

Table 1

Distribution of Respondents Based on Age of Toddlers Who Get Local PMT (BageaSasigo) in the Work Area of PuskesmasNambo, Kendari City

\begin{tabular}{c|c|c}
\hline Toddler Age (Month) & n & \% \\
\hline $8-20$ months & 29 & 43.3 \\
\hline $21-30$ months & 17 & 25.4 \\
\hline $31-40$ months & 15 & 22.4 \\
\hline$>40$ months & 6 & 9.0 \\
\hline amount & $\mathbf{6 7}$ & $\mathbf{1 0 0}$
\end{tabular}

Source: Primary data processed in 2020

Table 2

Distribution of Respondents Based on Age of Toddlers Who Get Government PMT (Biscuits) in the Work Area of PuskesmasNambo, Kendari City

\begin{tabular}{c|c|c}
\hline Toddler Age (Month) & n & \% \\
\hline 8-20 months & 15 & 22.4 \\
\hline $21-30$ months & 16 & 23.9 \\
\hline $31-40$ months & 18 & 26.9 \\
\hline > 40 months & 18 & 26.9 \\
\hline amount & $\mathbf{6 7}$ & $\mathbf{1 0 0}$ \\
\hline
\end{tabular}

Source: Primary data processed in 2020

Table 3

Distribution of Respondents Based on Giving Local PMT (BageaSasigo) and using government PMT such as Biscuits in the Work Area of PuskesmasNambo, Kendari City

\begin{tabular}{|c|c|c|c|c|}
\hline \multirow{2}{*}{ PMT } & \multicolumn{4}{|c|}{ Measurement } \\
\cline { 2 - 5 } & \multicolumn{3}{|c|}{ Pre Test } & Post Test \\
\cline { 2 - 5 } & $\mathbf{n}$ & $\mathbf{\%}$ & 67 & \% \\
\hline Local (BageaSasigo) & 0 & 0 & 67 & 50 \\
\hline Biscuits & 0 & 0 & $\mathbf{1 3 4}$ & $\mathbf{1 0 0}$ \\
\hline amount & $\mathbf{0}$ & $\mathbf{0}$ &
\end{tabular}

Source: Primary data processed in 2020 
Table 4

Distribution of Respondents Based on Weight Gain before and after being given Local PMT (BageaSasigo) and Biscuits in the Regions

The work of PuskesmasNambo, Kendari City

\begin{tabular}{|c|c|c|c|c|}
\hline \multirow{3}{*}{ Weight } & \multicolumn{4}{|c|}{ Local PMT (BageaSasigo) } \\
\hline & \multicolumn{2}{|c|}{ Pre - Test } & \multicolumn{2}{|c|}{ Post - Test } \\
\hline & $\mathbf{n}$ & $\%$ & $\mathbf{n}$ & $\%$ \\
\hline Negative & 67 & 100 & 42 & 62.7 \\
\hline Positive & 0 & 0 & 25 & 37.3 \\
\hline amount & 67 & 100 & 67 & 100 \\
\hline
\end{tabular}

Source: Primary data processed in 2020

Table 5

Distribution of Respondents Based on Weight Gain before and after being given PMT (Biscuits) in the Regions

The work of PuskesmasNambo, Kendari City

\begin{tabular}{|c|c|c|c|c|}
\hline \multirow{3}{*}{ Weight } & \multicolumn{4}{|c|}{ Government PMT (Biscuits) } \\
\hline & \multicolumn{2}{|c|}{ Pre - Test } & \multicolumn{2}{|c|}{ Post - Test } \\
\hline & $\mathbf{n}$ & $\%$ & $\mathbf{n}$ & $\%$ \\
\hline Negative & 67 & 100 & 22 & 32.8 \\
\hline Positive & 0 & 0 & 45 & 67.2 \\
\hline amount & 67 & 100 & 67 & 100 \\
\hline
\end{tabular}

Source: Primary data processed in 2020

Table 6

Effectiveness based on increasing body weight before and after being given

Local PMT (BageaSasigo) in the region

The work of PuskesmasNambo, Kendari City

\begin{tabular}{|c|c|c|c|c|}
\hline Variable & Mean & SD & P-Value & n \\
\hline BageaSasigo Pre-Test & 9,370 & 1,7638 & 0.001 & 67 \\
\hline BageaSasigo Post Test & 9,494 & 1,7882 & 0,000 & 67 \\
\hline
\end{tabular}

Source: Primary data processed in 2020

Table 7

Effectiveness based on increasing body weight before and after being given

PMT (Biscuits) in the region

The work of PuskesmasNambo, Kendari City

\begin{tabular}{|c|c|c|c|c|}
\hline Variable & Mean & SD & P-Value & n \\
\hline Pre-Test Biscuits & 10,516 & 2,1709 & 0.001 & 67 \\
\hline Post Test Biscuits & 10,806 & 2,1672 & 0,000 & 67 \\
\hline
\end{tabular}

Source: Primary data processed in 2020 
Table 8

Differences in the effectiveness of weight gain before and after being given Local PMT (BageaSasigo) and Government PMT (Biscuits) in the Work Area of PuskesmasNambo, Kendari City

\begin{tabular}{|c|c|c|c|}
\hline Variable & Sig & Sig (2-tailed) & n \\
\hline BageaSasigo & 0.129 & 0.001 & 67 \\
\hline Biskuits & 0.052 & 0,000 & 67 \\
\hline
\end{tabular}

Source: Primary data processed in 2020

\section{DISCUSSION}

The Effectiveness of Giving Local PMT (Bagea Sasigo) to Toddlers in the Work Area of Nambo Primary health care, Kendari City

Before the main research was carried out, a food content test was conducted at the FMIPA Laboratory of Halu Oleo University to determine the nutritional content contained in Bagea food ingredients. After knowing the content, a preliminary research was carried out with the aim of finding out how to make the right bagea cake product so that the product could be consumed and to know the acceptability both in terms of color, aroma, texture and taste. The process of making sago, cassava and gonad flour which is used as the main ingredient in making bagea cakes begins with the mixing process of sago flour and cassava. The dry tapioca is then mashed using a dry blender at a speed of $8 \mathrm{rpm} /$ minute then sieved using a mesh size of 80 .

Bagea cake is a typical snack in the Kendari mainland. This cake has a dry texture a bit hard and tastes sweet and savory. Judging from the basic ingredients of the bagea cake made from sago, this bagea cake has a characteristic because besides it tastes good, this bagea cake is also unique because it is almost similar to biscuits(12).

In the manufacture of bagea cakes, the results of trials that produced a pretty good product in terms of color, aroma, texture and taste, where this trial took 1 day. This study shows that before being given the treatment, the under-five's weight was below the average so that at the time of measuring the Body Mass Index (BMI) the nutritional status category was lacking. The low nutritional status of children under five is caused by various factors including poor diet, infectious and comorbid diseases, income levels and unhealthy living conditions. Efforts that have been made by the Kendari City Health Office to overcome the problem of malnutrition are the management of malnourished toddlers at the Rumah Gizi.

Based on the results of the study showed that before being given treatment (Pre Test), namely Local PMT (Bagea Sasigo) for body weight amounted to 67 respondents $(100 \%)$ while after treatment (Post Test) was given Local PMT (Bagea Sasigo) for body weight in the fixed category. (negative) amounted to 42 respondents $(62.7 \%)$, meaning that they experienced significant changes before the treatment. Whereas for the positive category (increased) after getting treatment, namely the provision of Local PMT (Bagea Sasigo), amounting to 25 respondents (23.7\%), which means that there is a change in body weight but not significantly yet because respondents are not used to consuming Bagea Sasigo so that the level of energy and protein consumption of toddlers still not enough. The average toddler consumes rice as an energy source compared to snacks.

The texture and taste of bagea is an important component in increasing the appetite of toddlers because the sensitivity of the taste senses is influenced by the texture of the food. Foods that are dense or thick will provide slower stimulation to the senses. Texture also affects the appearance of the food served (Shukri, Hamzah, Halim, Isa, \& Sarbon, 2014). Therefore, the texture of this bagea is perfect for toddlers(13). 
Taste is a sensation that arises and is caused by a volatile or non-volatile chemical component that comes from natural or synthetic origin and occurs when eating or drinking. The volatile components are those that give off a taste of smell, give off top notes and evaporate quickly. The nonvolatile components provide the sensation of taste, namely sweet, bitter, sour and salty, do not give the sensation of smell but become a volatile medium and help withstand the evaporation of volatile components or can be simplified, namely the sensation produced by food and other chemical components when stimulating receptors in the sense of taste or taste on the tongue. These basic tastes are received by the receptors in the rash (tase buds)(14)

Bagea Sasigo is a snack made from sago, cassava and gonad. Bagea sasigo is a typical food of Southeast Sulawesi Province, but it is still new to children because it has a gonad taste compared to government biscuits which have a strawberry flavor and are loved by children.Prior to the intervention for under-five children with low body weight, the introduction of local PMT as early as possible through socialization or counseling to the community so that it can be accepted in the community related to local PMT which comes from basic ingredients of sago, cassava and gonad so that it has a liking value and acceptance for toddlers. and can be an alternative to increase the weight of children under five who experience loss of appetite.

The results of statistical tests show that of the 67 respondents who were given Local PMT (Bagea Sasigo) treatment before being given treatment (Pre Test) which was 9.4 times then after treatment (Post Test) by giving Local PMT (Bagea Sasigo) to 9.5 times. The difference between the average Bagea Sasigo Pre-Test and Post-Test is 0.1 times. Independent T-test obtained a P-Value of 0.001 at the pre-test and 0.000 at the time of the post-test $<0.05$, then Ha is accepted, so it is concluded that there is an effect of PMT Bagea Sasigo on increasing weight of children under five in the Work Area of Puskesmas Nambo, Kendari City.

\section{The Effectiveness of Giving} Government PMT (Biscuits) to Toddlers in the Work Area of Nambo Primary health care, Kendari City

The Government Supplementary Food Program (biscuits) in Puskesmas is a product of the Ministry of Health's central supplementary food. Supplementary food provision (PMT) has not reached the Minimum Service Standard (SPM) target for good nutritional status in children under five in the Kendari City area. This result is known from interviews with most mothers whose children are malnourished because there are some children under five who do not like the Ministry of Health Center's Supplementary food biscuitsthey prefer local supplements from their mothers(15), shows that several factors that can cause children under five to not consume PMT according to standards are the child's poor appetite so that the child does not want to spend PMT(16).

PMT recovery is an effort to overcome malnutrition. Functional Mixed Food Ingredients (BMC) are foods that are able to provide beneficial effects for health in addition to the nutritional effects that food has in principle(17). In this study, PMT was given, in the control group or given PMT biscuits to toddlers with low nutritional status. Additional food is given every day as a snack for four (4) weeks. PMT evaluation can be monitored through weight gain to determine weight gain. at the beginning and end of the PMT implementation. Toddlers in the low weight category with under nutritional status, aged 8- 59 months, are the priority targets for PMT recipients.

Measurements on the body weight / age anthropometric index before and after the Government PMT (Biscuits) showed that more children experienced changes in body weight with an increase of about 1-3 ounces. This is directly proportional to the level of consumption of children under five, in which these children consume PMT (biscuits) 
according to the determined standards. In contrast to toddlers who have not consumed PMT according to standards who do not experience changes in nutritional status, all children under five have gained weight, which is indicated by a positive value on changes in weight of children under five before and after Government PMT (biscuits).

The results showed that before being given treatment (Pre Test), namely Government PMT (Biscuits) for body weight amounted to 67 respondents $(100 \%)$ while after treatment (Post Test) was given Government PMT (Biscuits) for body weight category fixed (negative) totaled 22 respondents $(32.8 \%)$. Meanwhile, for the positive category (increased) after receiving treatment, namely the provision of Government PMT (Biscuits), amounting to 45 respondents $(67.2 \%)$ experienced a significant increase.

The results of the statistical test showed that of the 67 respondents who were given the Government PMT (Biscuits) treatment before being given the treatment (Pre Test), that was 10.5 times then after the treatment (Post Test) was given the Government PMT (Biscuits) to 11 times. The difference between the average Bagea Sasigo Pre-Test and Post-Test is 0.5 times. The results of the Independent T-test obtained a P-Value of 0.001 at the pre-test and 0,000 at the time of the post-test $<0.05$, then $\mathrm{Ha}$ is accepted, so it is concluded that there is an effect of Government PMT (Biscuits) on the increase in weight of children under five in the working area of Puskesmas Nambo Kendari City.

The results of this study are in line with research conducted by Retnowati at the Kelambu Community Health Center, Grobogan Regency, which stated that giving additional government food (biscuits) for 90 days can help increase body weight in undernourished toddlers with an average weight gain of around 2-4 ounces.
Differences in the Increased Provision of Local PMT (Bagea Sasigo) and Government PMT (Biscuits) for Toddlers in the Work Area of the Nambo Primary health care, Kendari City.

The manufacture of food such as bagea is a ready to use food (RUF) which is suitable for preventing and handling malnutrition has the potential to increase nutritional yield(18). The results of the Government PMT form show that children under five with a higher percentage of Government PMT (biscuits) consume more than the percentage who consume Local PMT (Bagea Sasigo). The difference in the results of the statistical test results for weight / height and weight / age index can be caused by the sensitivity of $\mathrm{BW} / \mathrm{U}$ which is relatively high to sudden small changes and affects the results of weight measurement, while the indicator of height at weight / height has a lower sensitivity level to nutritional deficiency in the long term. short time (16).

Statistical test results show that of the 67 respondents, the sig. Levene's Test for Equality of Variances on bagea sasigo is $0.129>0.05$, it means that the variance of the Case group data is Homogeneous or the same(19). While for the Biscuits the amount of 0.052> 0.05, it means that the data variance of the Control group is Homogeneous or the same.

Based on the independent sample test output table in the Equal Variances Assumed section on Local PMT (Bagea Sasigo), it is known that the sig (2-tailed) value is 0.001 $<0.05$, so $\mathrm{Ha}$ is accepted so that there is a significant difference between the provision of local PMT (Bagea Sasigo). Whereas in the Government PMT (biscuits) it is known that the sig (2-tailed) value is $0.000<0.05$, so $\mathrm{Ha}$ is accepted so that there is a significant difference between the provision of government PMT (biscuits) to toddlers in the Work Area of the Puskesmas Nambo, Kendari City.

Research conducted by Salma in 2016 explained that the iron $(\mathrm{Fe})$ content in the 
gonads of diadema setosum in 100 grams of $1.00 \mathrm{mg}$ is almost equal to that of salmon of $1.50 \mathrm{mg}$. Thus, diadema setosum gonads are very suitable as additives in the diet of pregnant women who require appropriate Fe. Iron is needed for the manufacture of hemoglobin $(\mathrm{Hb})$, which is an oxygen transporter to tissues(20).

\section{CONCLUSION}

Giving Local PMT (Bagea Sasigo) and PMT Government (Biscuits) to children under five before the intervention was not effective while after the intervention was effective and significant. Shouldmaking bagea is used as an alternative food for toddlers with the composition of sago starch: 50\%, cassava flour: $50 \%$ and gonad: $20 \%$. To increase the favorite value of bagea and appetite for toddlers with the addition of various flavors of both chocolate, vanilla and strawberry to add to the taste of bageasasigo so that it attracts toddlers' interest in consuming the bagea.

\section{REFERENCES}

1. World Helath Organization. World health statistics 2015: World Health Organization; 2015.

2. DinkesProv. Toddler nutritional status. Southeast Sulawesi2017.

3. Rajasekaran A, Kalaivani M. Designer foods and their benefits: A review. Journal of food science and technology. 2013; 50 (1): 1-16.

4. Santosa H. Enzymatic Hydrolysis of Tapioca Starch with Combination of Microwave-Water Bath in Dextrins Making. Momentum. 2010; 6 (2).

5. Denas S. Effect of Local-Based Food Supplementation and Optimization of Father's Support on Changes in Levels of Albumin, Hemoglobin, Immunoglobulin A, and Anthropometry in Undernourished Children in Padang Pariaman Regency: Andalas University; 2016.
6. Doren WK, Regaletha TA, Dodo DO. Evaluation of the Recovery Supplementary Food Program (PMT-P) on the Malnutrition Status of Toddlers at the Oepoi Health Center, Kupang City. Lontar: Journal of Community Health. 2019; 1 (3): 111-8.

7. Nutrition DB. Health of both mother and child. Guidelines for Organizing Supplementary Foods for Undernourished Toddlers Jakarta: Kemenkes RI. 2011.

8. Erpridawati DD. The relationship between knowledge about nutrition and nutritional status of junior high school students in Kerjo sub-district, Karanganyar district: Muhammadiyah University of Surakarta; 2012.

9. Rahayu A, Khairiyati L. The risk of mother's education on the incidence of stunting in children 6-23 months. Nutrition and Food Research. 2014; 37 (2): 129-36.

10. Mackey A, Gass SM. Second language research: Methodology and design: Routledge; 2015.

11. Sugiyono. Nonparametric Statistics for Research. 2015.

12. Hidayah Z. Encyclopedia of ethnic groups in Indonesia: Yayasan Pustaka Obor Indonesia; 2015.

13. Banudi L, Anasiru MA, Petrus P, Leksono P. A Bagea Formulation Made From Cassava Starch Extract and Gonad Diadema Setosum (Sea Urchins) as an Alternative Food for Pregnant Women. Health Information: Research Journal. 2017; 9 (2): 18-26.

14. Zuliana C, Widyastuti E, Susanto WH. Making Coconut Ants Sugar (Study of Coconut Sugar $\mathrm{Ph}$ and Sodium Bicarbonate Concentration) [IN PRESS JANUARI 2016]. Journal of Food and Agroindustry. 2015; 4 (1).

15. Rakhmawati NZ, Panunggal B. Relationship between knowledge and attitudes of mothers with maternal behavior in providing food for children 
Rasyid, M., T. Supodo, \& L. Banudi. DOI: 10.36566/ijhsrd/Vol3.Iss1/53

https://ijhsrd.com/index.php/ijhsrd

aged 12-24 months: Diponegoro University; 2014.

16. Rini I, Pangestuti DR, Rahfiludin MZ. The Effect of Supplementary Recovery Food (PMT-P) on the Change in Nutritional Status of Malnourished Toddlers in 2017 (Study at the Semarang City Nutrition House). Journal of Public Health (e-Journal). 2017; 5 (4): 698-705.

17. Juhartini J. The Effect of Supplementing Biscuits and Mixed Food Ingredients of Moringa on Body Weight and Hemoglobin Studies of Infants with Thin Nutritional Status in the Work Area of the Kalumpang Health Center, Ternate City, 2015. Hospital Majapahit (Health Scientific Journal of the Majapahit Health Polytechnic, Mojokerto). 2016; 8 (2).

18. Owino V. Why lipid-based ready to use foods (RUF) must be key components of strategies to manage acute malnutrition in resource poor settings Victor Owino. 2010.

19. Sujarweni VW. Research methodology: Complete, practical, and easy to understand. Yogyakarta: Pustakabarupress. 2014.

20. Salma I, Németh Z, Kerminen VM, Aalto P, Nieminen T, Weidinger T, et al. Regional effect on urban atmospheric nucleation. Atmospheric Chemistry and Physics. 2016. 